\title{
Tecnura
}

\section{Guided Models for Teaching Students Research in Science and Engineering}

\section{Modelos guiados para la investigación en ingeniería y ciencias básicas}

\author{
Adriana Patricia Gallego Torres ${ }^{1}$, Edier Hernán Bustos Velazco ${ }^{\circledR}$, \\ Jaime Duván Reyes Roncancio ${ }^{3}$
}

Fecha de recepción: 4 de Febrero de 2020

Fecha de aceptación: 13 de Agosto de 2020

Cómo citar: Gallego-Torres ., A.P. Bustos-Velazco., E.H. y Reyes-Roncancio., J.D. (2020). Guided Models for Teaching Students Research in Science and Engineering. Tecnura, 24(66), 85-94. https://doi.org/10.14483/22487638.16133

Abstract

Context: This article presents the arguments that support the formulation of a research model from the idea of "guided models," which allows the designing of routes and methodologies for the approaching, formulating, and solving problems in the training of technologists and engineers.

Method: The methodology used was based on grounded theory, which allows solving problems and develop innovative research through theoretical and methodological categories.

Results: It was possible to organize the model with a special emphasis on the generation of monitoring and contrasting matrices as a control mechanism and guide for the researcher.

Conclusions: The implications of the incorporation of this model are analyzed in relation to the training purposes of engineering and technology professionals, articulated through a progression hypothesis as a reference every researcher will be able to get when analyzing and reviewing their own research processes regardless of the methodology developed.

Keywords: models, methodology, informed theory, investigation, training.

\section{Resumen}

Contexto: En este artículo se presentan los argumentos que fundamentan la formulación de un modelo de investigación desde la idea de "modelos guiados," que permite el diseño de rutas y metodologías para el planteamiento, formulación y resolución de problemas en la formación de tecnólogos e ingenieros.

Método: La metodología utilizada se basa en la teoría fundamentada, la cual permite por medio de categorías teóricas y metodológicas resolver problemas y desarrollar investigaciones innovadoras.

Resultados: Se obtuvo la organización del modelo, con especial énfasis en la generación de matrices de seguimiento y contrastación, como mecanismo de control y guía para el investigador.

Conclusiones: Las implicaciones de la incorporación de este modelo se analizan en relación con los propósitos de formación de profesionales de la ingenieria y de la tecnología, articulándose mediante una hipótesis de progresión como referencia que puede tener todo investigador al momento de analizar y revisar sus propios procesos de indagación, independientemente de la metodología que se desarrolle.

Palabras clave: modelos, metodología, teórica fundamentada, investigación, formación.

1 Doctor en Física. Licenciada en Física. Docente Titular, Universidad Distrital Francisco José de Caldas. Bogotá, Colombia. Contacto: adpgallegot@udistrital.edu.co

2 Doctor en Educación, Licenciado en Matemáticas. Docente Titular Universidad Distrital Francisco José de Caldas. Bogotá, Colombia. Contacto: ehbustos@udistrital.edu.co

3 Doctor en Educación, Licenciado en Física. Docente Titular Universidad Distrital Francisco José de Caldas. Bogotá, Colombia. Contacto: jdreyesr@udistrital.edu.co 


\section{INTRODUCTION}

This work aims to contribute to research training in initial and continuing teaching of methodological processes in three main areas. First, by formulating guided models for the construction of theories both in the practice and implementation of strategies, as well as in routes for the resolution of research problems (Gallego-Badillo R. , 2004). Secondly, with the foundation of methodological designs that help guide research in engineering and science with the purpose of understanding scientific research processes. Third, by formulating the bases for the constitution of methodological guides, specifically dedicated to the training of researchers (Giraldo, 2011) (Gangoso, 2016).

From this perspective, this work is based on four guidelines. In the first place, the need to start from the construction of guided models, in other words, the methodological definition of the models as part of the construction of knowledge, which could be applied both in the training of researchers and for school science. Second, an epistemological foundation from the formulation and construction of theoretical categories. Third, a methodological proposal in accordance with said paradigm from grounded theory, whose starting point is the approach of a guided model of the phenomenon under investigation. This proposal is especially operative when it comes to building master's theses. And finally, methodological routes and hypothesis of progression to conclude with an example of construction and application of the proposal.

\section{METHODOLOGICAL PERSPECTIVE IN RESEARCH TRAINING}

Throughout the history of natural science, the importance of formulating models that explain everything from natural phenomena to the structure of the universe itself has been widely documented. From this perspective, we propose a work oriented to research processes. This work is developed from two strategies: formulating models and establishing methodologies that allow configuring a work route in order to generate new and better ways of building knowledge (Niaz, 2016) (Da Rochaa, 2019).

From the importance of science education and model-based teaching arises the need to build a proposal of guided models for research training in Technology, Engineering, and Basic Sciences. Therefore, a guided model is proposed accompanied by a systematic review of both theoretical references and scientific production (Gómez and Garduño, 2020), in order to establish a solid support for the system (Chamizo-Guerrero \& Ríos-López, 2017) (Arraiz, 2014). In other words, it is necessary to generate conceptual structures in students within a system framed in a model that would grant them several advantages. For example, the model will allow them both to understand the problem and to postulate hypothetical scenarios for the solution; that is, it will give them tools for the construction of innovative methodological designs that give them a guide to solve the problem and generate new ways of approaching science and technology education (Acevedo-Díaz \& al, 2017) (Bosque-Pérez \& al, 2016) (Sánchez-Robayo \& Torres-Duarte, 2017). Additionally, it allows them to construct a representation of the degree work within an epistemological framework.

This proposal is based on the concept of model proposed by Ingham and Gilbert (1991). They argued that a model is a simplified representation of a system that focuses attention on specific aspects of it (Peralta, 2016). Furthermore, models allow aspects within the system (i.e. objects, events, or ideas) that are complex or that are on a different scale than the system itself. Models are important for scientific research in the formulation of hypotheses to be tested, as well as in the description of scientific phenomena (Ingham \& Gilbert, 1993).

In summary, this proposal seeks to contribute to the development of the next generation of researchers. In particular, the objective is to help the development of skills that allow them, on the one hand, to pose problems and evaluate them, and on the other, to provide solutions with an emphasis on the construction of models to guide research and innovation processes.

Tecnura • p-ISSN: 0123-921X • e-ISSN: 2248-7638 • Vol. 24 No. $66 \bullet$ Octubre - Diciembre de $2020 \bullet$ pp. 85-94 


\section{FROM GROUNDED THEORY TO THE ESTABLISHMENT OF MODELS IN RESEARCH AS A WORK ROUTE}

In order to formulate a theory of guided models for research training, we turn to what is stated by Strauss and Corbin called "Grounded Theory," understood as the possibility of innovating with the generation of models that allow explaining a phenomenon (Glaser \& Strauss, 1967). In particular, this research focuses on two types of phenomena related to the natural sciences and technology (Weiss, 2017) (Ovalle, 2019): on the one hand, those phenomena linked to the daily action of human beings; on the other, to those generated by nature itself.

Finally, it is important to take into account what is called "the four phases of all hermeneutical research." These phases are a) instrument validation; b) implementation; c) methods and tools for the collection and systematization of information; and d) the qualitative or quantitative analysis of the information (i.e. triangulation and analysis) (Carrero, 2012).

\section{Grounded theory}

The grounded theory was initially defined by Glaser and Strauss, who in 1967 published a book called "The Discovery of Grounded Theory" where they developed it (Glaser \& Strauss, 1967). After this publication, many researchers have adopted this proposal whose purpose is to construct concepts that are derived from the registered and systematized information of experiences in which social researchers live experiences with communities (Hernández, Herrera, Martínez, \& Páez, 2011). Grounded Theory (or "research training" in this case) adopts a mixed methodological paradigm (Medina, Arguello \& Gómez, 2017) that allows the construction of guided models, which is the modeling of research proposals according to the intentions of every investigation. In this way, the conceptualization becomes an abstract and simplified perspective, as knowledge of the lived world and that the researcher wants to represent through the construction of models that, in the case of this investigation, is applied to the teaching of science (Arraiz, 2014) (Bonilla-García \& López-Suárez, 2016).

Our proposal to work on guided models based on grounded theory for the training of researchers is structured around five moments:

1. Formulation of the model: systems of questions, objectives, and hypotheses posed as a system.

2. Presentation of theoretical categories by induction as a guide for mapping bibliographic information and conceptual foundation of research (Contreras Accounts, 2020). As many categories as concepts that are formulated in the problem will be proposed.

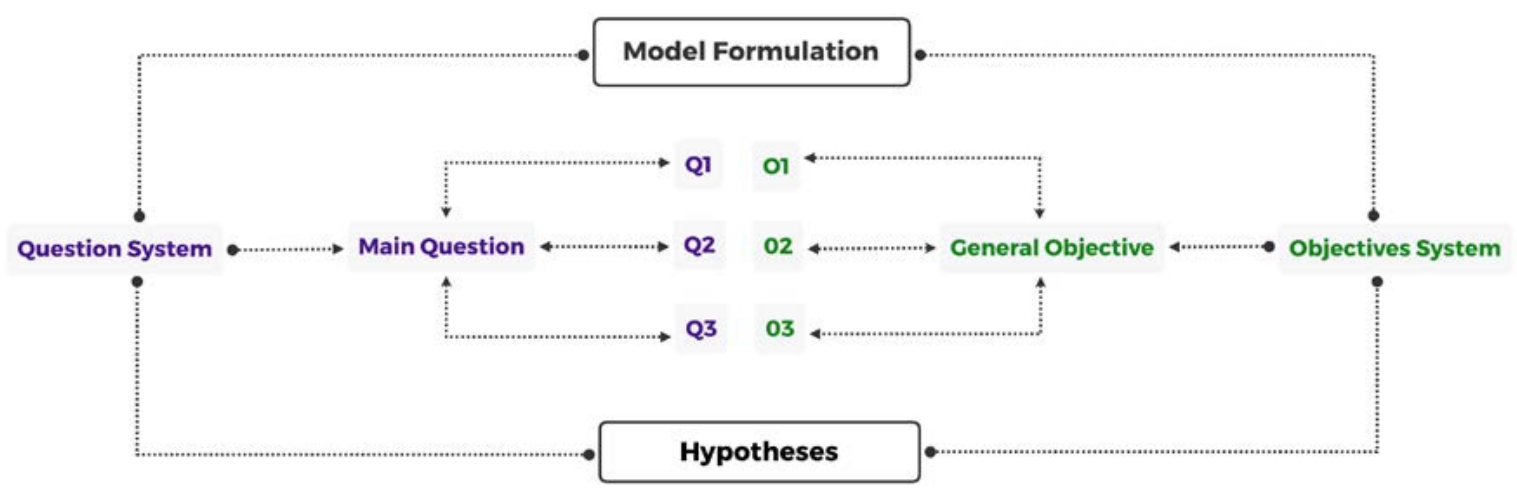

Figure 1. Formulation of the model.

Source: Own.

Tecnura • p-ISSN: 0123-921X • e-ISSN: 2248-7638 • Vol. 24 No. $66 \bullet$ Octubre - Diciembre de $2020 \bullet$ pp. 85-94 
Table 1. Category matrix.

\begin{tabular}{|c|c|c|c|c|c|}
\hline $\begin{array}{l}\text { RESEARCH } \\
\text { PROBLEM }\end{array}$ & $\begin{array}{l}\text { GENERAL } \\
\text { OBJECTIVE }\end{array}$ & $\begin{array}{c}\text { SPECIFIC } \\
\text { OBJECTIVES }\end{array}$ & CATEGORIES & $\begin{array}{l}\text { CATEGORY } \\
\text { DEFINITION }\end{array}$ & SUBCATEGORIES \\
\hline
\end{tabular}

Source: Own

3. Design of the methodological route: Construction of methodological designs, and the validation process of the instruments and activities that constitute the researcher's field work (Cisterna, 2005). This validation is carried out by entities, which are three differentiated actors, in order to give ownership and reliability to the research. These three actors are: a) academic peers of the researcher, b) experts, and c) a similar population group (Paramo-Bernal, 2018).

4. Implementation: The proposed designs are applied, the data obtained is systematized, and the information is triangulated (Richards, 2018). The systematization process can be qualitative or quantitative, with the need to go through writing techniques and semantic codes configured in the interpretation of the validated instruments (phase two). In this sense, it is important to use specialized software for the qualitative and quantitative analysis of information (e.g. MAXQDA $®$, Atlas-Ti $\Re, N-V i v o \circledR$, SPSS $($ ) (Chandra \& Shang, 2019)

5. Modeling and Analysis. In this last phase, the researcher validates his hypotheses and tests the solution to the problem from the initial model. This process allows either a reconfiguration of the initial model or the reconfiguration of the initial approach and conclusions (Campeón, Becerra, \& Villa, 2018).

The follow-up to this methodological process, shown in Figure 2, secures the development of a systematic and reliable work, which will guarantee that the obtained results contribute to the scientific community dedicated to education. This greatly benefits future researchers who pursue a hermeneutical education.

\section{THE DESIGNING AND IMPLEMENTING OF GUIDED MODELS IN THE INVESTIGATIVE PROCESS}

In this section we will address an interpretive approach to the idea of guided models for research training in a dynamic and reflective sense. Thus, the concept of model is presented in association with factors that enhance its dialogic-reflective character. These factors also serve to structure a trajectory as a form of argued representation of the methodological route, via specific representations of maps of the process (Gutierrez, 2016). A generic example of representation of models and methodological maps is distinguished.

This organization helps to consolidate a new look at what is done when researching in science education because it questions the monitoring of phases (stages) and the mechanical use of techniques (methods), without reflecting on the events of the research process. Additionally, this option positions the conception of the reflective researcher, who is epistemologically aware of the differences between the application of research methods (from their various enunciations) and the design and implementation of problem-solving routes. This awareness of the difference applies even in cases in which mixed-cut methodological alternatives that dialogue with the construction of models and progression hypotheses are developed (Gallego-Badillo, Pérez, \& Gallego-Torres, 2020). 


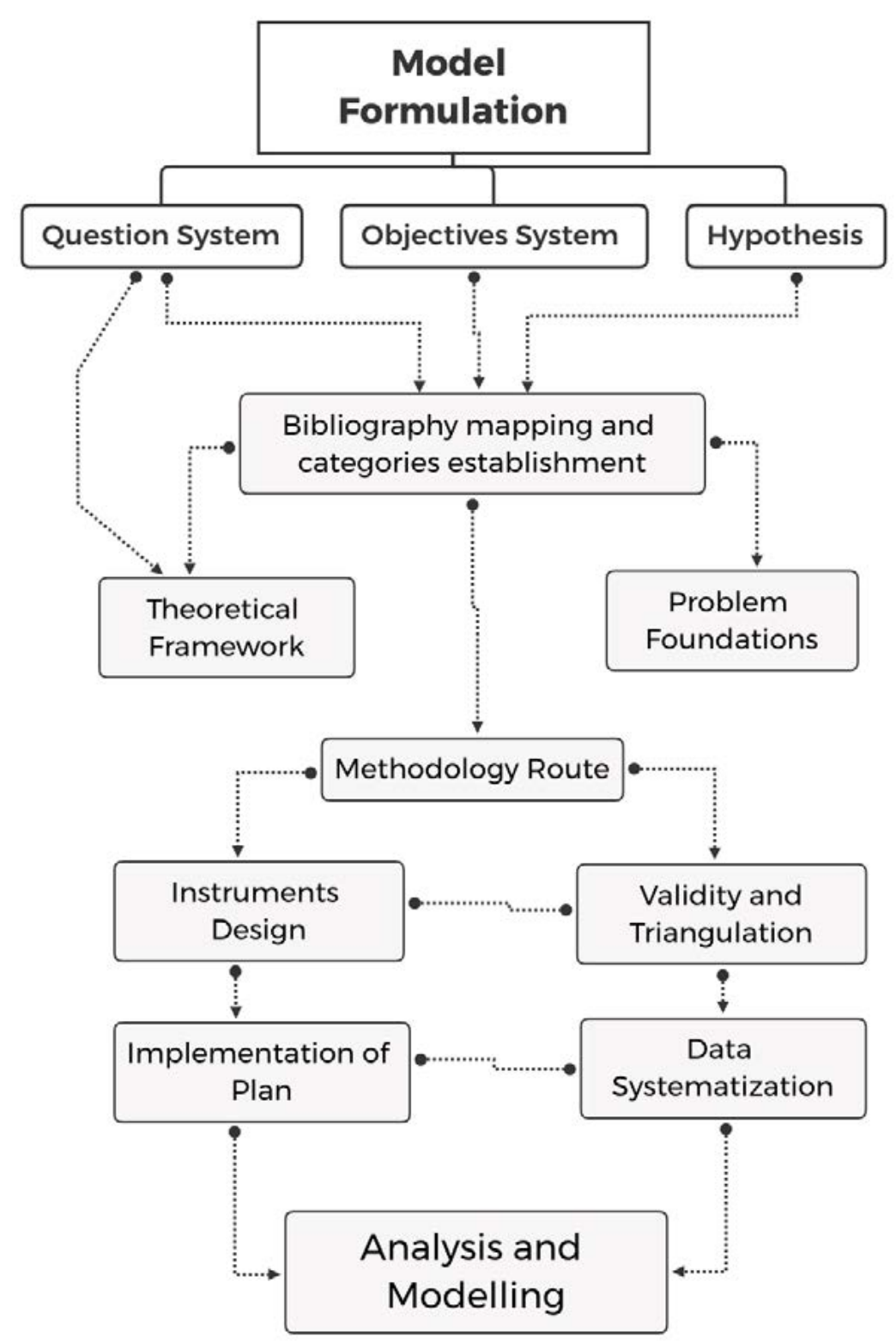

Figure 2. Guided Model for Research Training.

Source: Own.

\section{Guided Models for Research Methodologies}

The concept of "guided model" in research acquires relevance insofar as it allows understanding the process of solving the research problem from a dynamic, active, reflective, and also changing and complex approach. However, these characteristics do not imply that the process is difficult or impossible. Another characteristic feature of the concept is the validation of the research in a praxiological sense; this favors the construction of meaning in actions, based on the reflection over the experiences of researchers and their work team (Arango-Londoño, 2016). For this reason, the guided model is enriched by the 
contexts of reflection, the researcher's learning and the validation and feedback processes from experts.

Consequently, when the research process is beginning, the design of methodological models from the aforementioned approach is appropriate for the case of epistemological and hermeneutical perspectives. This is due to the constructive nature of knowledge that is produced and is applicable, for example, in the field of science education.

\section{Factors that enhance the guided model}

According to the researcher's reflected experience on his own inquiry processes, research actions are consolidated as elements or factors of the investigative process. For the first case, the researcher can assume that the methodology consists of considering relevant aspects that are added or achieved as they solve their research problem question. For the second case, it can be assumed that the aspects associated with the methodology are like turning points in their maximum potential, that is, they are capable of reconstructing different paths to follow; these alternatives are proposed from a qualification perspective, not a denial, of those initially proposed. Thus, in the case of methodological trajectories, it is necessary to consider dynamic factors rather than disconnected elements.

A guided model can be designed with the following factors in mind:

1. The epistemological perspective on the nature of knowledge that is produced. It is necessary to consciously assume whether the knowledge that is produced obeys the researcher's particular philosophical views (e.g. realism or relativism), since this also gives value to the researcher's own knowledge.

2. The organization of threads. These are usually understood as phases of the investigation and are designs of possible routes of inquiry associated with the objectives of the investigation.
3. The constitution of meaning for the threads. What are they developed for? What do they contribute? Why are they necessary?

4. The progressive approach to the process through the threads. The researcher's actions must be continually reflected in such a way as to build a progressive awareness of the process. Therefore, it is not about developing the threads like a recipe in which predetermined steps are followed; on the contrary, each reflected investigative action contributes to the indicated meaning. Thus, the reconstruction processes of the corresponding methodological experiences are facilitated.

It is worth noting that this description does not refer to specific investigative techniques. This is because the techniques are selected or constructed to the extent that their characteristics enhance particular actions of the researcher. Although this is not an obstacle to consider them in the planning of the sub-processes, it should never be assumed in a dogmatic sense as it would be contradictory with the dynamic approach that we have presented.

\section{Guided models and progression hypotheses as a reference map}

When organizing the research design from guided models, it is possible to establish a progression hypothesis as a reference map. In this sense, the progression hypothesis acquires relevance to contrast and reflect on the coherence of the methodological path (Figure 2). The factors are considered as criteria and in each of these it is convenient to analyze the "places" of reference. As a synthesis, it is possible to deduce a map that reveals a state of the guided model; In addition, it is possible to make maps at the beginning, during, and at the end of the investigative process. In this way, not only would there be evidence of the methodological transformation route as a product, but also the progression hypothesis would be fed back. 
Table 2. Reference progression hypothesis for the representation of methodological routes.

\begin{tabular}{|c|c|c|c|}
\hline \multicolumn{4}{|c|}{ Progression hypothesis in a guided model } \\
\hline & A & B & C \\
\hline $\begin{array}{l}\text { [E] } \\
\text { Epistemological perspective } \\
\text { of the knowledge that is } \\
\text { produced }\end{array}$ & $\begin{array}{l}\text { A1: mainly positivist, } \\
\text { A2: realistic approach } \\
\text { associated with the expla- } \\
\text { nation of the subject-object } \\
\text { relationship. }\end{array}$ & $\begin{array}{l}\text { B1: transitional, in process of } \\
\text { reflection, } \\
\text { B2: argues with positivism in } \\
\text { the construction of explana- } \\
\text { tions. }\end{array}$ & $\begin{array}{l}\mathrm{C} 1: \text { a perspective of construction } \\
\text { of reality is assumed for the object } \\
\text { of study, } \\
\text { C2: analyze the role of epistemo- } \\
\text { logical relativism. }\end{array}$ \\
\hline $\begin{array}{l}\text { [SP] } \\
\text { The organization of threads }\end{array}$ & $\begin{array}{l}\text { A3: isolated steps of the } \\
\text { process are distinguished, } \\
\text { A4: phases are listed as } \\
\text { steps to develop. }\end{array}$ & $\begin{array}{l}\text { B3: some thread relationships } \\
\text { are built, } \\
\text { B4: some factors distinguished } \\
\text { (dynamic perspective of some } \\
\text { threads). }\end{array}$ & $\begin{array}{l}\text { C3: Consistent relationships are } \\
\text { established between threads } \\
\text { C4: factors are characterized } \\
\text { C5: Threads are related to the } \\
\text { research question } \\
\text { C6: dynamic perspective of } \\
\text { threads is displayed }\end{array}$ \\
\hline $\begin{array}{l}\text { [ADV] } \\
\text { The constitution of meaning } \\
\text { for the threads }\end{array}$ & $\begin{array}{l}\text { A5: sense associated with } \\
\text { following plans or recipes } \\
\text { (mainly positivist approach). }\end{array}$ & $\begin{array}{l}\text { B5: sense in relation to some } \\
\text { threads, } \\
\text { B6: reflective approach in ne- } \\
\text { gotiation with the alternative } \\
\text { epistemological gaze. }\end{array}$ & $\begin{array}{l}\text { C7: sense of thread in corres- } \\
\text { pondence with the alternative } \\
\text { epistemological gaze, } \\
\text { C8: the dynamic sense is eviden- } \\
\text { ced in the reflective processes } \\
\text { developed. }\end{array}$ \\
\hline $\begin{array}{l}\text { [PRG] } \\
\text { The progressive approach } \\
\text { to the process through the } \\
\text { threads. }\end{array}$ & $\begin{array}{l}\text { A6: an additive perspective } \\
\text { of progression prevails }\end{array}$ & $\begin{array}{l}\text { B7: a thoughtful look at the } \\
\text { progression for some threads } \\
\text { B8: reflective tendency to } \\
\text { maintain additive focus in } \\
\text { some cases }\end{array}$ & $\begin{array}{l}\text { C9: reflective-critical approach to } \\
\text { the progression of all threads, } \\
\text { C10: factor qualification complex } \\
\text { approach } \\
\text { C11: development of enrichment } \\
\text { processes for research categories. }\end{array}$ \\
\hline
\end{tabular}

Source: Own

\section{Examples of Guided Model as Synthesis}

Regardless of the stage of development of the methodological process, it is possible to construct a representation as a reference map (Figure 3). This allows identifying the state of the process or reflecting and redirecting actions in order to qualify the methodological route as such. Thus, the route acquires meaning for the researcher and her work team (a dynamic, critical and reflective sense) instead of being addressed as a set of instructions or rigid steps.

When representing the guided model from the elaboration of reference maps based on the hypothesis of progression, consider the following example. Figure 3 shows the organization and state of reflection on the design and development of a hypothetical methodological process. From this, it is possible to recreate a way to orient ourselves in our own methodological path.

From the categories of the progression hypothesis, levels A, B, and C have been selected. In these, the researcher has reflected and is in a moment of reflection both personally and with his team. This yields the representation of maps (Figure 4) that are represented as a methodological route given that the process is dynamic and reflective. As shown, the example has three maps corresponding to three moments (review, reflection, discussion), based on the factors of the progression hypothesis. With this, it is posible to give an account of the methodological route developed. 


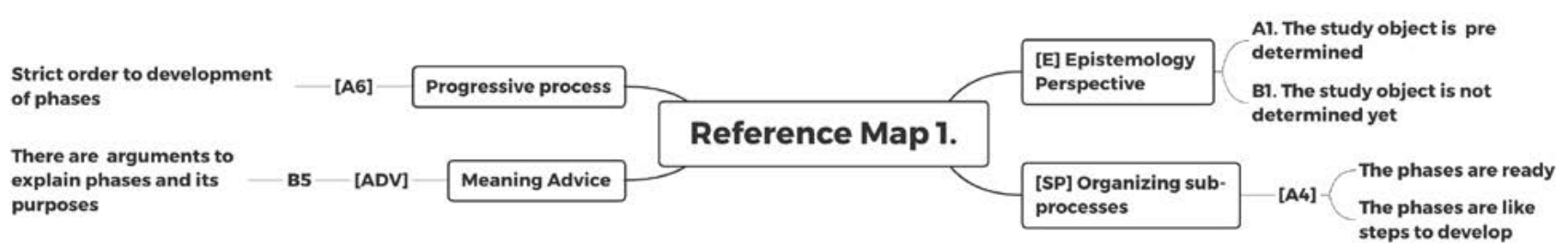

Figure 3. Reference Map.

Source: Own.

\begin{tabular}{|c|c|c|c|}
\hline \multicolumn{5}{|c|}{ MAP 1 } \\
METHODOLOGICAL \\
ROUTE \\
\hline & A & B & C \\
\hline$[E]$ & A1 & B1 & \\
\hline$[$ SP] & A4 & & \\
\hline$[$ ADV] & A6 & & \\
\hline$[$ PRG] & & B5 & \\
\hline
\end{tabular}

\begin{tabular}{|c|c|c|c|}
\hline \multicolumn{5}{|c|}{ MAP 2 } \\
METHODOLOGICAL \\
ROUTE \\
\hline & A & B & C \\
\hline$[E]$ & & & \\
\hline$[$ SP] & & & \\
\hline$[$ ADV] & & & \\
\hline$[$ PRG] & & & \\
\hline
\end{tabular}

\begin{tabular}{|c|c|c|c|}
\hline \multicolumn{5}{|c|}{ MAP 3 } \\
METHODOLOGICAL \\
ROUTE \\
\hline & A & B & C \\
\hline$[E]$ & & & \\
\hline$[$ SP] & & & \\
\hline$[$ ADV] & & & \\
\hline$[$ PRG] & & & \\
\hline
\end{tabular}

Figure 4. Methodological routes.

Source: Own.

\section{CONCLUSIONS}

The guided model is an alternative for the collective and autonomous monitoring of inquiry processes, and it requires the construction of conceptual references such as progression hypotheses.

It is worth highlighting that this is the first of several works that have been prepared within the line of emphasis on research, and we hope to continue deepening and presenting results to the community of specialists.

\section{BIBLIOGRAPHY}

Acevedo-Díaz, J. A., \& al, e. (2017). Modelos científicos: significado y papel en la práctica científica. Revista Científica, 3(30), 155-166. HYPERLINK "https://doi. org/10.14483/23448350.12288" \t“_blank" https:// doi.org/10.14483/23448350.12288
Adúriz-Bravo, A., \& Gallego-Torres, A. (2016). Scientific Research and its pedagogical uses. Revista Científica, 2(25), 160-161. HYPERLINK "https:// doi.org/10.14483/udistrital.jour.RC.2016.25.a0" \t “_blank" https://doi.org/10.14483//udistrital.jour. RC.2016.25.a0

Arango-Londoño, C. H.-Z.-M.-Á. (2016). Construcción e implementación de un estudio de caso como herramienta de apoyo a los procesos de aprendizaje en la asignatura de producción desde un enfoque constructivista. Ingeniare(21), 109-125. HYPERLINK “https:// doi.org/10.18041/1909-2458/ingeniare.21.403" It "_blank" https://doi.org/10.18041/1909-2458/ ingeniare.21.403

Arraiz, G. (2014). Teoría fundamentada en los datos: un ejemplo de investigación cualitativa aplicada a una experiencia educativa virtualizada en el área de matemática. Revista Virtual Universidad Católica del Norte(41), 19-29. 
Bonilla-García, M., \& López-Suárez, A. (2016). Ejemplificación del proceso metodológico de la teoría fundamentada. Cinta de moebio(57), 305-315. HYPERLINK "https://doi.org/10.4067/S0717554X2016000300006" \t “_blank" https://doi. org/10.4067/S0717-554X2016000300006

Bosque-Pérez, N., \& al, e. (2016). "A pedagogical model for team-based, problem-focused interdisciplinary doctoral education. BioScience, 6(66), 447-488. HYPERLINK “https://doi.org/10.1093/biosci/biw042" It "_blank" https://doi.org/10.1093/biosci/biw042

Campeón, M., Becerra, E., \& Villa, J. (2018). Ingeniería didáctica para el aprendizaje de la función lineal mediante la modelación de situaciones. Sophia, 14(2), 115-126. HYPERLINK "https://doi. org/10.18634/sophiaj.14v.2i.629" \t “_blank" https://doi.org/10.18634/sophiaj.14v.2i.629

Carrero, V. S. (2012). Teoría fundamentada. El desarrollo de teoría desde la generalización conceptual. Madrid: Cuadernos Metodológicos.

Chamizo-Guerrero, J. A., \& Ríos-López, G. (2017). Diseño y evaluación de una estrategia didáctica para enseñar a preguntar. Revista Científica, 1(28), 32-40. HYPERLINK "https://doi.org/10.14483/udistrital.jour.RC.2017.28.a3" \t “_blank" https://doi. org/10.14483/udistrital.jour.RC.2017.28.a3

Chandra, Y., \& Shang, L. (2019). Computer-Assisted Qualitative Research: An Overview. Qualitative Research Using R: A Systematic Approach, 21-31. HYPERLINK "https://doi.org/10.1007/978981-13-3170-1_2" \t “_blank" https://doi. org/10.1007/978-981-13-3170-1_2

Cisterna, F. (2005). Categorización y triangulación como procesos de validación del conocimiento en investigación cualitativa. . En Theoria, 14(1), 61-71.

Contreras Cuentas, M. M. (2020). La teoría fundamentada como metodología de construcción teórica. Revista científica Pensamiento y Gestión, 1-10.

Corcho, O., Fernández-López, M., \& Gómez-Pérez, A. \&.-C. (2005). Construcción de ontologías legales con la metodología METHONTOLOGY y la herramienta WebODE. Recuperado el 13 de junio de 2018, de https://core.ac.uk/download/pdf/11994341.pdf

Da Rochaa, E. F. (2019). La interdisciplinariedad como camino epistemológico de la formación de profesores en Ciencias de la Naturaleza. . Latin American Journal of Science Education, 6, 1-10.

Gallego-Badillo, R. (2004). Un concepto epistemológico de modelo para la. Revista Electrónica de Enseñanza de las Ciencias, 3(3), 301-319. HYPERLINK "https:// doi.org/10.1163/9789004409088_009" \t "_blank" https://doi.org/10.1163/9789004409088_009

Gallego-Badillo, R., Pérez, R., \& Gallego- Torres, A. \&. (2020). Research on Colombian Science Teachers' Education: A Review. Science Education Research in Latin America, 207-226.

Gangoso, Z. (2016). Investigaciones en resolución de problemas en ciencias. Investigações em ensino de ciências, 4(1), 7-50.

Giraldo, M. (2011). Abordaje de la investigación cualitativa a través de la teoría fundamentada en los datos. Ingeniería Industrial. Actualidad y Nuevas Tendencias, 79-86.

Glaser, B., \& Strauss, A. (1967). Grounded theory in the 21st Century. Chicago: Denzin NK, Lincoln YS (editors).

Gómez-Romero,. J.A., y Garduño-Román., (2020). Desarrollo sustentable o desarrollo sostenible, una aclaración al debate. Tecnura, 24(64). 117-133. https://doi.org/10.14483/22487638.15102

Gutierrez, R. (2016). Polisemia actual del concepto "modelo mental". Consecuencias para la investigación didáctica. 10(2),. Investigações em Ensino de Ciências, 10(2), 209-226.

Hernández, J. G., Herrera, L., Martínez, R., \& P. J. (2011). (2011). Teoría fundamentada. Seminario: Generación de Teoría. Facultad de Humanidades y Educación, Universidad del Zulia. Zulia: Universidad de Zulia.

Ingham, A., \& Gilbert, J. (1993). El uso de modelos analógicos por estudiantes de química en el nivel de educación superior. Revista Internacional de $E d$ ucación en Ciencias, 2(13), 193-202.

Medina, R., Arguello, H \& Gómez, C. (2017). A quantitative and qualitative performance analysis of compressive spectral imagers. Revista Tecnura, 21(52), 53-67. doi: 10.14483/udistrital.jour.tecnura.2017.2.a04 https://doi.org/10.14483/udistrital. jour.tecnura.2017.2.a04 
Navarro Mejía, D. (2015). El animal se está comiendo su cola. La génesis y evolución de un proyecto educativo de Educación Superior. Revista Tecnura, 19, 179-190. doi: 10.14483/udistrital.jour.tecnura.2015. SE1.a16

Niaz, M. (2016). History and philosophy of science as a guide to understanding nature of science. Revista científica, 1(24), 7-16. HYPERLINK "https://doi. org/10.14483/udistrital.jour.RC.2016.24.a1" \t “_blank" https://doi.org/10.14483/udistrital.jour. RC.2016.24.a1

Ovalle, B. (2019). La teoría fundamentada como método de investigación cualitativa para explicar la ausencia del estado en los diferentes niveles de emprendimientos. Revista Científica de la Investigación y el Conocimiento, 3(1), 742-761. HYPERLINK "https://doi.org/10.26820/recimundo/3. (1).enero.2019.742-761" \t “_blank" https://doi. org/10.26820/recimundo/3.(1).enero.2019.742-761

Paramo-Bernal, P. (2018). La Investigación en Ciencias Sociales: Técnicas de recolección de la información. Bogotá: Universidad Piloto de Colombia. HYPERLINK “https://doi.org/10.2307/j.ctv7fmfjk" \t " blank" https://doi.org/10.2307/j.ctv7fmfjk

Peralta, E. (2016). Teoría general de los sistemas aplicada a modelos de gestión. . Aglala, 7(1), 122-145. doi:DOI 10.22519/22157360.901

Richards, K. A. (2018). A practical guide to collaborative qualitative data analysis. Journal of Teaching in Physical Education, 37(2), 225-231. HYPERLINK “https://doi.org/10.1123/jtpe.2017-0084" \t "_ blank" https://doi.org/10.1123/jtpe.2017-0084

Robles, A., Solbes Matarredona, J., Cantó Doménech, J., \& Lozano, L. (2015). Actitudes de los estudiantes hacia la ciencia escolar en el primer ciclo de la Enseñanza Secundaria Obligatoria. Revista Electrónica de Enseñanza de las Ciencias, 14(3), 361-376.

Saltelli, A., \& Funtowicz, S. (2017). What is science's crisis really about? Futures(91), 5-11. HYPERLINK “https://doi.org/10.1016/j.futures.2017.05.010" \t"_ blank" https://doi.org/10.1016/j.futures.2017.05.010

Sánchez-Robayo, B., \& Torres-Duarte, J. (2017). Aprender a investigar investigando. Realización de una propuesta de formación. Revista científica, 1(28), 17-13. HYPERLINK “https://doi.org/10.14483/udistrital.jour.RC.2017.28.a2" \t “_blank" https://doi. org/10.14483/udistrital.jour.RC.2017.28.a2

Trejos Buriticá, O. I. (2015). Metodología para la formulación de proyectos basada en la definición del problema. Revista Tecnura, 19(45), 115-126. doi: 10.14483/udistrital.jour.tecnura.2015.3.a09 https:// doi.org/10.14483/udistrital.jour.tecnura.2015.3.a09

Weiss, E. (2017). Hermenéutica y descripción densa versus teoría fundamentada. Revista mexicana de investigación educativa, 22(73), 637-654.

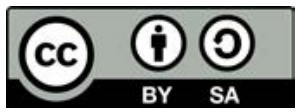

Tecnura • p-ISSN: 0123-921X • e-ISSN: 2248-7638 • Vol. 24 No. $66 \bullet$ Octubre - Diciembre de $2020 \bullet$ pp. 85-94 